\title{
Use of GUS Transformants of Fusarium subglutinans for Determining Etiology of Mango Malformation Disease
}

\author{
Stanley Freeman, Marcel Maimon, and Yaakov Pinkas
}

Department of Plant Pathology, ARO, The Volcani Center, P.O. Box 6, Bet Dagan 50250, Israel.

Y. Pinkas is deceased.

Accepted for publication 23 February 1999.

\begin{abstract}
Freeman, S., Maimon, M., and Pinkas, Y. 1999. Use of GUS transformants of Fusarium subglutinans for determining etiology of mango malformation disease. Phytopathology 89:456-461.

Fusarium subglutinans has been associated with mango floral and vegetative malformation, although confusion exists regarding the etiology of the disease. A wild-type isolate of $F$. subglutinans causing mango malformation disease was transformed with the GUS ( $\beta$-glucuronidase) reporter and hygromycin resistance genes. Five stable transformants were isolated containing varying copy numbers at different integration sites. Specific GUS activity was quantified for the transformants, whereas no
\end{abstract}

ABSTRACT activity was recorded for the wild-type isolate. The transformants and the wild-type isolate were inoculated into healthy mango floral and vegetative buds. Typical symptoms of misshapen shoots with short internodes, stubby leaves, and bunchy, malformed inflorescences were observed 6 to 8 weeks following inoculation. The presence of GUS-stained mycelium of the pathogen viewed microscopically within infected plant organs provided unequivocal evidence that $F$. subglutinans is indeed a causal agent of mango malformation disease.

Additional keywords: Fusarium moniliforme, Fusarium spp., Mangifera indica.
Inflorescence and vegetative malformation of mango, Mangifera indica $\mathrm{L}$., is one of the most important diseases of this crop and occurs in most mango-growing countries worldwide $(11,22)$. Serious losses are caused by the disease, since malformed inflorescences do not bear fruit. Although mango malformation was first reported over a century ago in India, the epidemiology and etiology of the disease is poorly understood and confusion still exists regarding the causal agents $(11,22)$. Physiological theories have been postulated as disease incitants such as altered $\mathrm{C} / \mathrm{N}$ ratio (2) and lack of chelated iron $(1,15)$. Viruses have also been suggested as causal disease agents (26), although results from electron microscopy, transmission, cultural, and serological studies have disproved this theory $(9,10)$. Presence of the Aceria (Eriophyes) mangifera mite has been attributed to the cause of mango malformation (7, 16); however, certain studies indicate that the mite may only play a role in wounding and transfer of a fungal pathogen $(22,27)$. Certain studies have associated the phytopathogenic fungus Fusarium subglutinans (Wollenweb. \& Reinking) P.E. Nelson, T.A. Toussoun, \& Marasas (basionym: F. moniliforme J. Sheld. var. subglutinans Wollenweb. \& Reinking) with malformation (11), with further studies supporting the evidence that mango malformation is caused by the fungus $F$. subglutinans $(3,14,21,31)$. However, additional recent publications still cast doubt on the fact that the fungus $F$. subglutinans is the responsible disease incitant $(13,20)$. Although the pathogen reported responsible for mango malformation had been identified in the past as $F$. subglutinans, the precise taxonomic classification of the fungus remains undefined (18).

In this study, we used GUS transformants of $F$. subglutinans isolate 506/2 to assess the infection potential in mango floral and vegetative tissues and to provide unequivocal evidence that this fungus is indeed a causal agent of mango malformation disease.

Corresponding author: S. Freeman; E-mail address: freeman@ netvision.net.il

Publication no. P-1999-0322-02R

(C) 1999 The American Phytopathological Society

\section{MATERIALS AND METHODS}

Fungal culture, growth, and transformation. The wild-type F. subglutinans isolate 506/2 from infected mango inflorescences at The Volcani Center plantation (originally identified by P. E. Nelson, Pennsylvania State University, and A. Z. Joffe, The Hebrew University of Jerusalem, Israel) was maintained on potato dextrose agar (PDA) at $25^{\circ} \mathrm{C}$. Isolate $506 / 2$ was transformed with a plasmid (pGPD-GUS; provided by D. Straney, University of Maryland) containing the GUS ( $\beta$-glucuronidase) reporter and hygro-

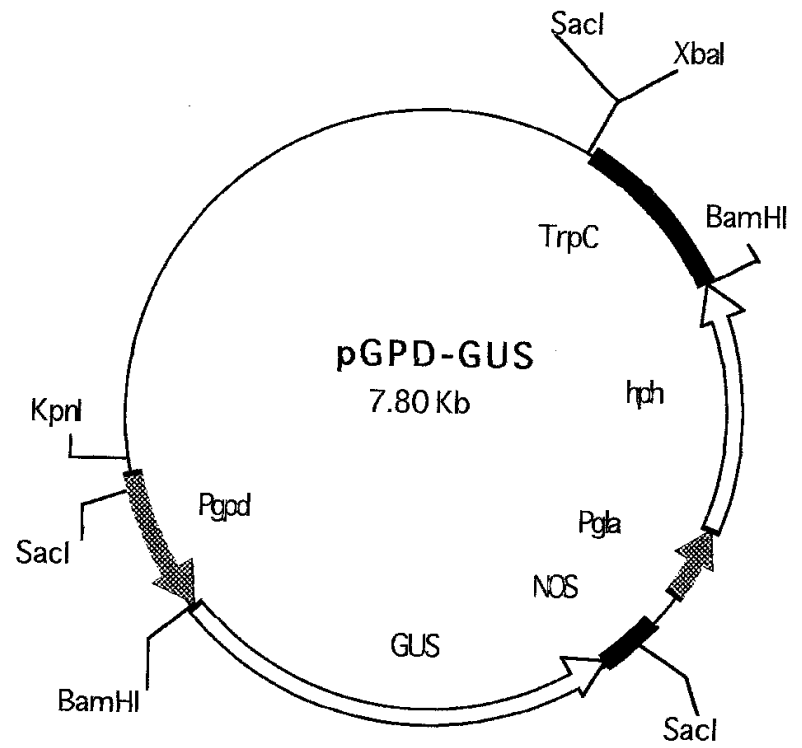

Fig. 1. A partial restriction digest map of pGPD-GUS, a pBluescript-based plasmid, that is $7.8 \mathrm{~kb}$ in length containing the hygromycin phosphotransferase gene (hph) under control of the Aspergillus niger Pgla promoter and $\operatorname{Trp} C$ terminator, and the $\beta$-glucuronidase (GUS) reporter gene under control of the Cochliobolus heterotrophus Pgpd promoter and NOS terminator (provided by D. Straney, University of Maryland). 
mycin resistance genes (Fig. 1). Plasmid transformation was obtained using a polyethylene glycol-mediated protoplast protocol, after first plating on PDA amended with hygromycin $(100 \mu \mathrm{g} / \mathrm{ml})$ (Boehringer $\mathrm{GmbH}$, Mannheim, Germany), as previously described (23). The wild-type isolate and derived transformants of $F$. subglutinans used in this study were further classified by K. O'Donnell, Peoria, IL, as a Fusarium sp., indicating that the pathogen is conspecific with NRRL 25266 = IMI 304063 ex mangifera from India (18). Identification was based on sequence and amplification of the beta tubulin gene using primers $\mathrm{T} 1 \times \mathrm{T} 22$ and primer $\mathrm{T} 21$ to sequence across three introns at the $5^{\prime}$ end of the gene (17).

Pathogenicity on mango. All stable transformants and the wildtype isolate 506/2 were tested for pathogenicity on mango trees (cv. Kent) maintained under greenhouse conditions for 30 days at diurnal temperatures of 9 to $17^{\circ} \mathrm{C}$ for flower induction and thereafter at 17 to $22^{\circ} \mathrm{C}$. Wound inoculation was performed by injecting $20 \mu \mathrm{l}$ of conidial suspensions $\left(5 \times 10^{7}\right.$ conidia per $\left.\mathrm{ml}\right)$ of each isolate into dormant apical buds, six buds per isolate on separate branches per tree. Symptoms were observed 6 to 8 weeks after inoculation, and percent infection was calculated. Inoculation experiments were also conducted on unwounded tissue by placing a $10-\mu l$ drop of conidial suspension $\left(5 \times 10^{7}\right.$ conidia per $\mathrm{ml}$ ) on dormant buds. Inoculation experiments were conducted twice.

GUS activity. For histopathological studies, GUS activity was monitored microscopically in inoculated infected and noninoculated plant tissues that were removed from the trees 6 to 8 weeks after inoculation $(6,8,19,30)$. Conidia of Fusarium sp. transformants and the wild-type fungus were isolated from infected tissue and germinated on PDA containing $50 \mu \mathrm{g}$ of 5-bromo-4-chloro-3-indolyl$\beta$-D-glucuronic acid (X-Gluc; Duchefa, Haarlem, the Netherlands) per $\mathrm{ml}$ dissolved in $10 \% \mathrm{NN}$-dimethylformamide (Sigma Chemical

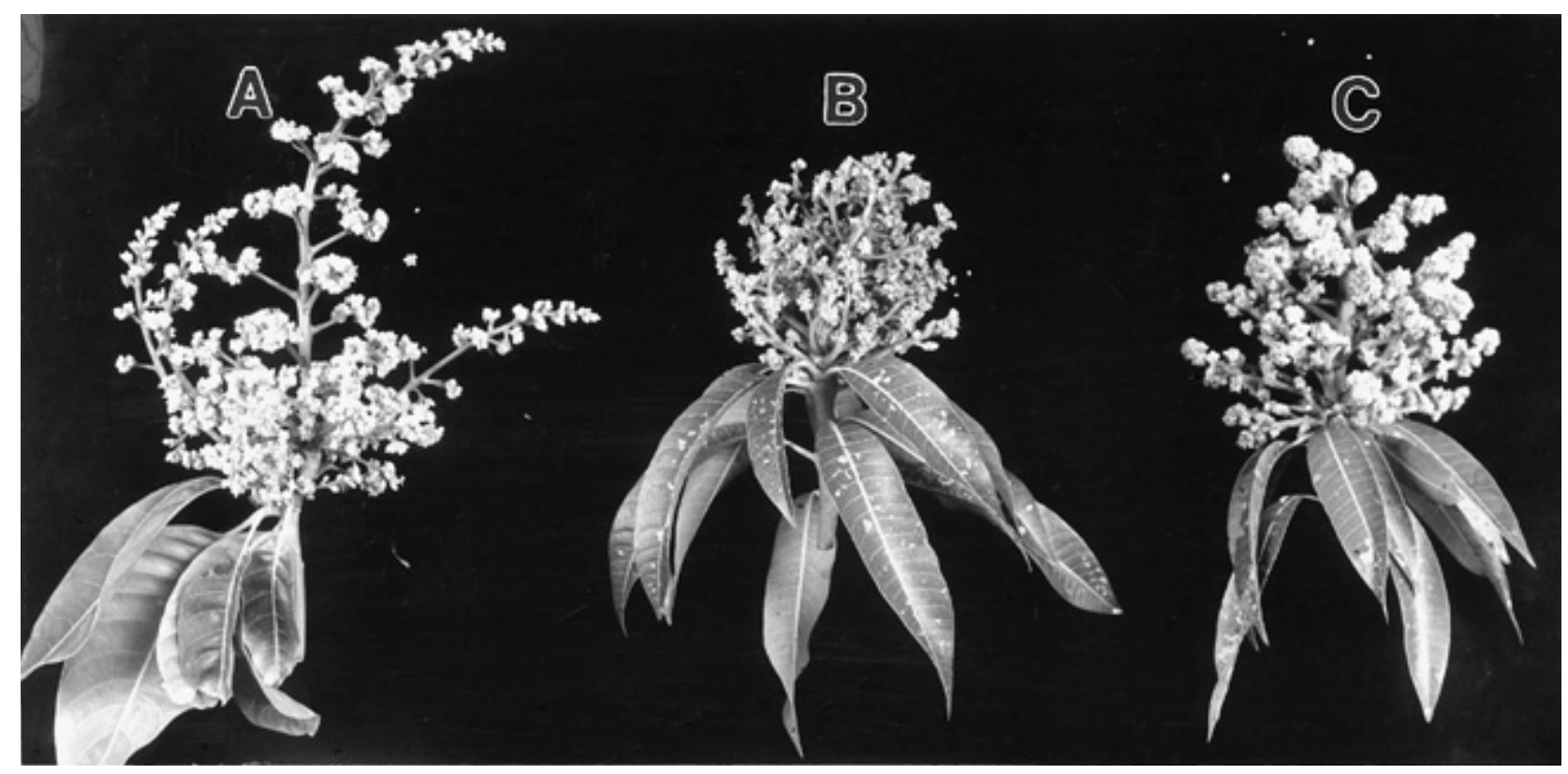

Fig. 2. A, Healthy and typical floral malformation of mango artificially inoculated with B, the GUS transformants and C, the wild-type isolate of Fusarium subglutinans.

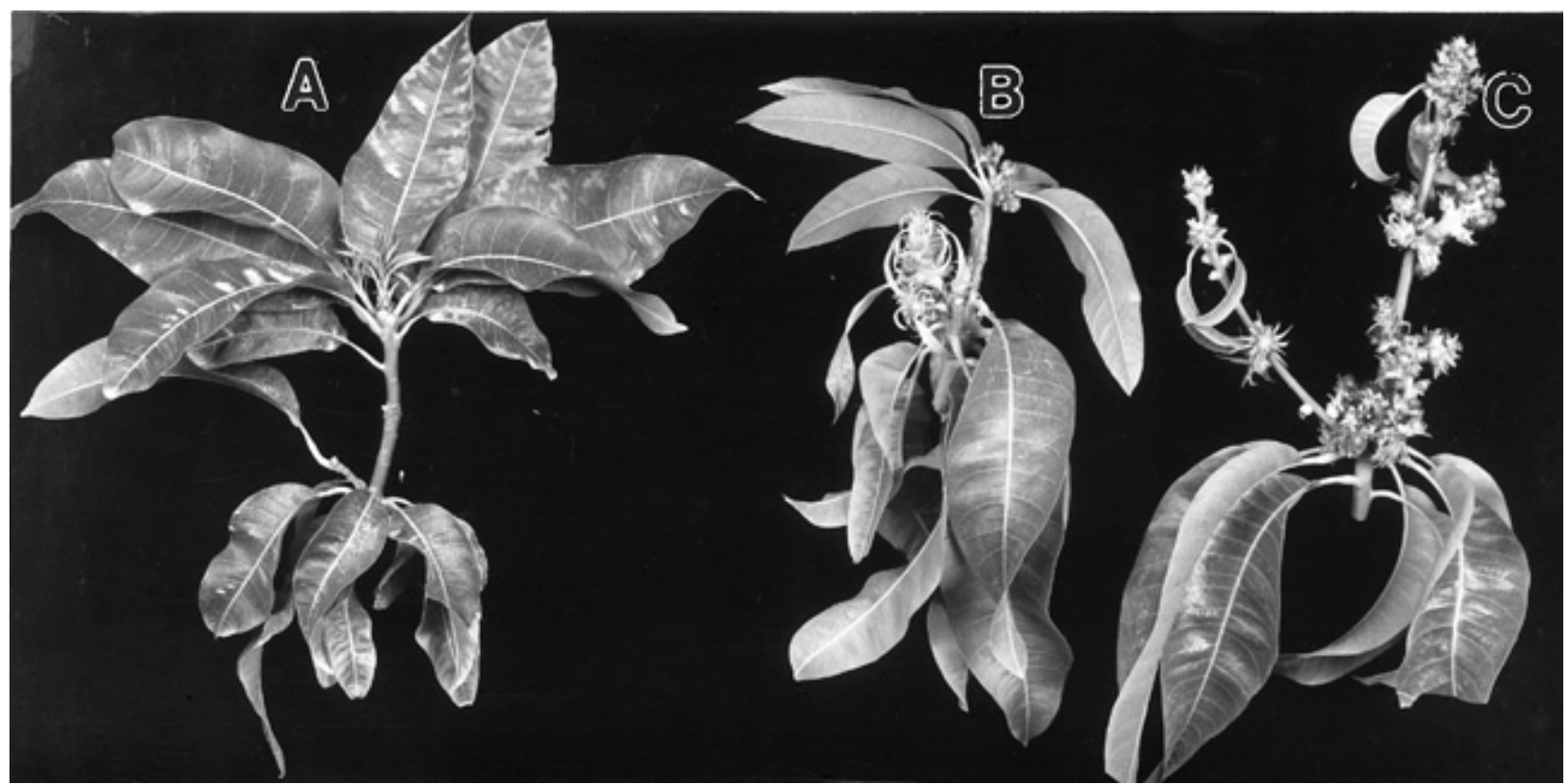

Fig. 3. A, Healthy and typical vegetative malformation of mango artificially inoculated with B, the GUS transformants and $\mathbf{C}$, the wild-type isolate of Fusarium subglutinans. 
Co., St. Louis). To detect GUS-stained mycelium in infected mango tissue, a reagent mix containing $50 \mu \mathrm{g}$ of X-Gluc per $\mathrm{ml}, 0.1 \mathrm{M}$ $\mathrm{NaPO}_{4}(\mathrm{pH} 7.0), 10 \mathrm{mM}$ EDTA, and $0.5 \mathrm{mM}$ each of Kferri- and ferrocyanide in $0.05 \%$ (vol/vol) Triton-X was vacuum-infiltrated into plant tissues for 5 min $(6,8)$. Plant tissues were cleared of chlorophyll by washing twice over a 48 -h period in chloral hydrate $(120 \mathrm{~g}$ per $100 \mathrm{ml}$ ) (Sigma Chemical Co.) and viewed using a Wild stereomicroscope (Wild, Heerbrugg, Switzerland) (28).
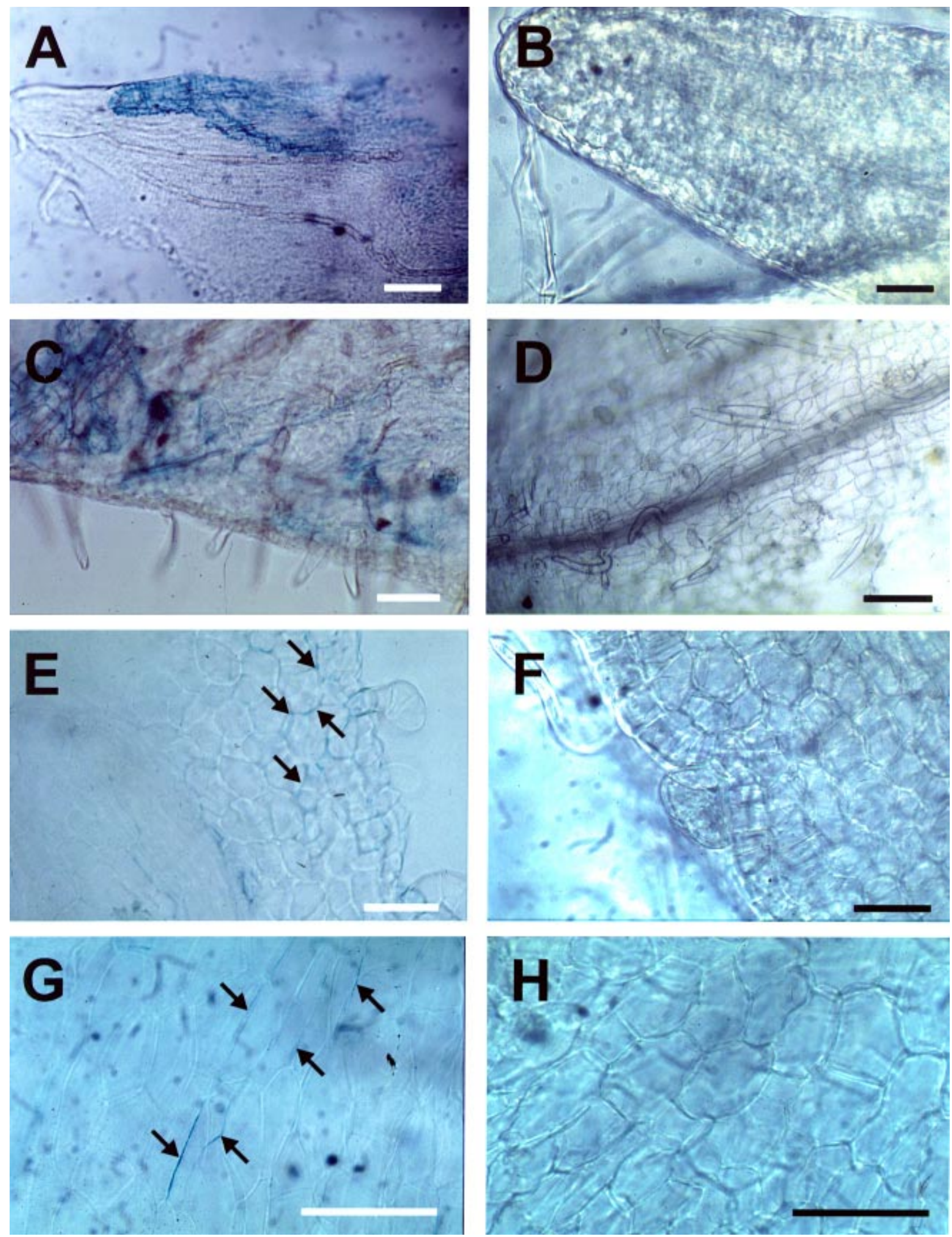

Fig. 4. Histochemical localization of GUS activity in Fusarium subglutinans from mango A, in leaf primordia; $\mathbf{C}$, in sepal; E, within pedicel; and $\mathbf{G}$, within nectar glands. B, D, F, and $\mathbf{H}$, GUS-stained mycelia were not evident in the respective noninoculated controls. Bars $=\mathbf{A}$ and $\mathbf{B}, 133 \mu \mathrm{m} ; \mathbf{C}$ and $\mathbf{D}, 100 \mu \mathrm{m} ; \mathbf{E}$, $75 \mu \mathrm{m} ; \mathbf{F}, 50 \mu \mathrm{m}$; and $\mathbf{G}$ and $\mathbf{H}, 20 \mu \mathrm{m}$. Arrows denote GUS-stained mycelia within sectioned tissue. 
GUS activity of the transformants and the wild-type isolate was also quantified in extracts of mycelium using the 4-methyl-umbelliferyl $\beta$-D-glucuronide (MUG) (Duchefa) fluorometric assay $(6,8,19)$. Mycelium was grown for 7 days in still culture on potato dextrose broth and lyophilized till dry. Thereafter, $0.16 \mathrm{~g}$ of mycelium of each culture was ground in liquid nitrogen and suspended in $10 \mathrm{ml}$ of GUS extraction buffer consisting of $50 \mathrm{mM} \mathrm{NaHPO}$ (pH 7.0), $10 \mathrm{mM} \beta$-mercaptoethanol, $10 \mathrm{mM} \mathrm{Na}_{2}$ EDTA, $0.1 \%$ so-
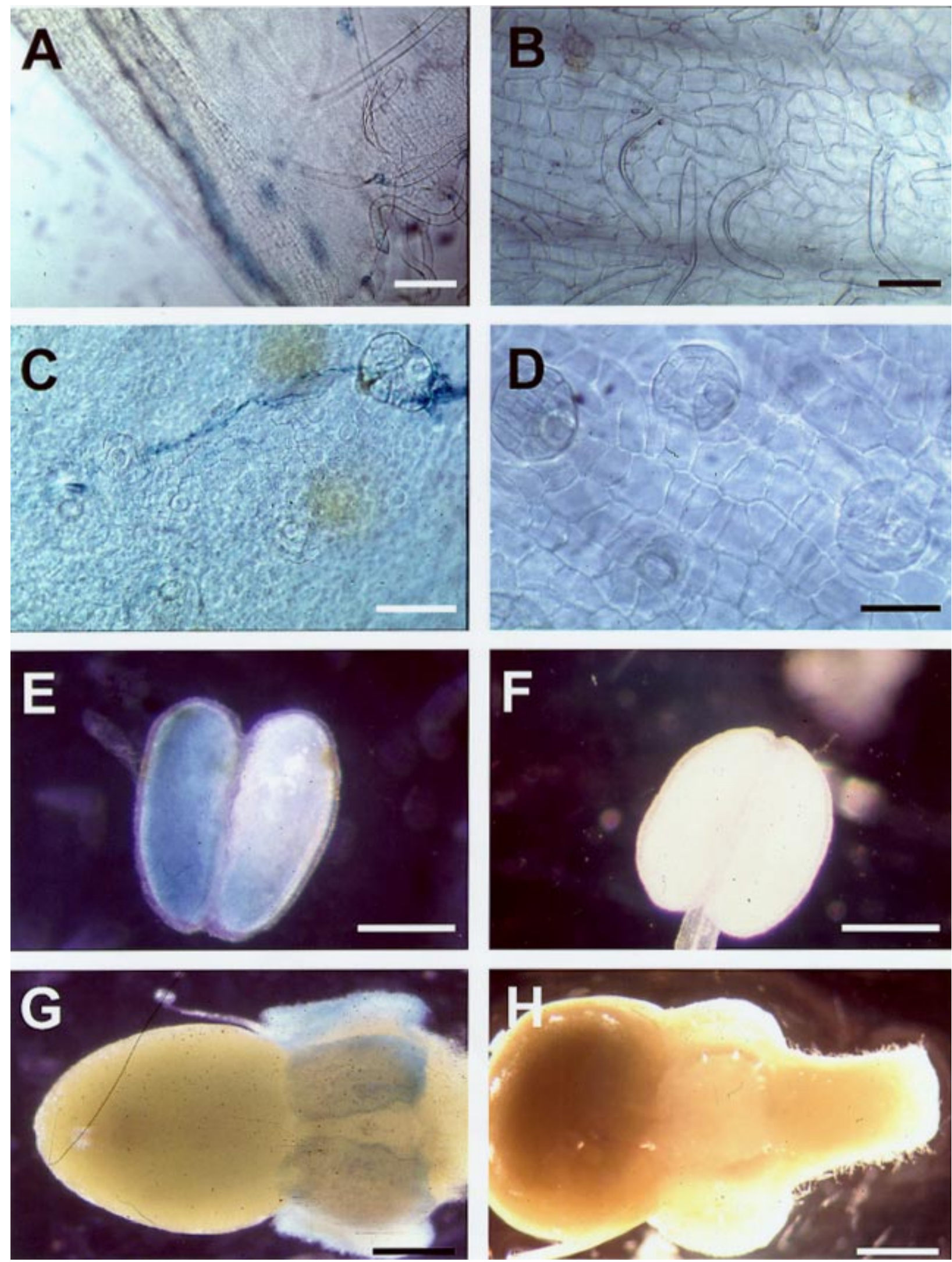

Fig. 5. Histochemical localization of GUS activity in Fusarium subglutinans from mango in A and C, trichomes; E, anther sacs; and G, nectar glands at fruit set. B, D, F, and H, GUS-stained mycelia were not evident in the respective noninoculated controls. Bars = A, $100 \mu \mathrm{m} ; \mathbf{B}, 75 \mu \mathrm{m} ; \mathbf{C}, 75 \mu \mathrm{m} ; \mathbf{D}, 50 \mu \mathrm{m} ; \mathbf{E}$ and $\mathbf{F}$, $166 \mu \mathrm{m}$; and $\mathbf{G}$ and $\mathbf{H}, 1.5 \mathrm{~mm}$. 
dium dodecyl sulfate, and $0.1 \%$ Triton X-100 $(6,8)$. The suspension was mixed for $2 \mathrm{~min}$ in an Ultra-turrax T 25 (IKA-Labortechnik, Staufen, Germany) on ice, centrifuged for $20 \mathrm{~min}$ at $8,500 \times g$, and filtered through a $0.2-\mu$ filter. A MUG solution was added at a rate of $0.2 \mathrm{ml}$ per $0.15 \mathrm{ml}$ of filtrate and incubated in the dark at $37^{\circ} \mathrm{C}$. The reactions were stopped at $0-, 30-$, and 60 -min intervals by adding $0.05 \mathrm{ml}$ of $0.2 \mathrm{M} \mathrm{Na}_{2} \mathrm{CO}_{3}$. GUS activity was measured at an optical density of $405 \mathrm{~nm}$ using a TKO 100 fluorometer (Hoefer Scientific Instruments, San Francisco, CA) and expressed as nanomoles per minute per milligrams of protein. This experiment was conducted twice.

DNA extraction and molecular analysis of integration events. DNA extraction procedures were performed on the wild-type isolate 506/2 and the stable transformants, as previously described (4, $5,12,24,25)$. A digoxigenin-high prime DNA luminescent labeling and detection kit was used for nonradioactive nucleic acid labeling and detection (Boehringer $\mathrm{GmbH}$ ). The organization of integrated pGPD-GUS in transformants was determined by digesting genomic DNA with KpnI, which has a unique site on the plasmid (Fig. 1), and by performing Southern blot hybridization with luminescentlabeled pGPD-GUS.

\section{RESULTS}

GUS transformants. Twenty-two hygromycin-resistant transformants were originally obtained, whereas the wild-type $F$. subglutinans isolate 506/2 did not grow on this selection medium. Some transformed isolates did not express the GUS reporter gene after transferring to PDA plates supplemented with $50 \mu \mathrm{g}$ of $\mathrm{X}$ Gluc per ml. Ultimately, five stable transformants (GPD-1, GPD-7, GPD-8, GPD-18, and GPD-19) expressing both the GUS reporter and hygromycin resistance genes, were selected after subculturing at least five times over a 2-month period on amended and unamended PDA.

Pathogenicity tests. All five stable transformants caused typical malformation symptoms in vegetative and floral tissues, similar to the wild-type isolate 506/2, 6 to 8 weeks after inoculation in developing mango tissues (Figs. 2 and 3). Percent infection was $67,83,100,100,100$, and 100 for isolates GPD-7, GPD-1, GPD-8, GPD-18, GPD-19, and wild-type 506/2, respectively. Typical disease symptoms were also observed in unwounded inoculated tissue.

GUS staining and activity. Typical dark blue staining was observed in mycelium and conidia of transformed isolates and not in that of the wild-type control, isolate 506/2 (data not shown). GUSstained mycelia were detected in leaf primordia (Fig. 4A), in sepals (Fig. 4C), within a pedicel (flower stalk) (Fig. 4E), and within nectar glands (Fig. 4G). GUS-stained mycelia were not evident in noninoculated controls of leaf primordia (Fig. 4B), in sepals (Fig. 4D), within the pedicel (Fig. 4F), and within nectar glands (Fig. 4H). Likewise, GUS-stained mycelia were observed within trichomes (Fig. 5A and C), associated with anther sacs (Fig. 5E), and detected in nectar glands at early stages of fruit set (Fig. 5G), but not

TABLE 1. Specific activity of the GUS transformants and the wild-type isolate of Fusarium subglutinans as quantified by the 4-methyl-umbelliferyl $\beta$-D-glucuronide assay

\begin{tabular}{lc}
\hline Isolate & Specific activity $^{\mathrm{a}}$ \\
\hline Wild-type 506/2 & 0.0 \\
Transformant GPD-1 & $227.26 \pm 12.95^{\mathrm{b}}$ \\
Transformant GPD-7 & $228.57 \pm 5.83$ \\
Transformant GPD-8 & $456.26 \pm 6.09$ \\
Transformant GPD-18 & $430.41 \pm 2.76$ \\
Transformant GPD-19 & $44.28 \pm 4.30$ \\
\hline
\end{tabular}

${ }^{a}$ GUS activity (nmol/min/mg of protein) of the transformants and the wildtype isolate was quantified in extracts of mycelium, following 7 days of growth on potato dextrose broth.

${ }^{b}$ Data are the means \pm standard error. The experiment was conducted twice. in the respective noninoculated controls, trichomes (Fig. 5B and D), anther sacs (Fig. 5F), and nectar glands at fruit set (Fig. 5H). In addition, no fungi could be detected in noninoculated control tissue using aniline blue staining, whereas only typical $F$. subglutinans mycelia and conidia could be detected in mango tissue infected with transformed and wild-type isolates using this stain (data not shown).

Specific GUS activity of the transformants and the wild-type isolate was quantified in extracts of mycelium and found to range from 227.26 to $430.41 \mathrm{nmol} / \mathrm{min} / \mathrm{mg}$ of protein for the transformants, whereas no activity was recorded for the wild-type isolate 506/2 (Table 1).

Molecular analysis of transformants. pGPD-GUS hybridized to undigested genomic DNA from each of the five transformants, but not to DNA of the wild-type isolate 506/2 (data not shown). The patterns of integration were complex and differed for all transformants when hybridized to genomic DNA digested with KpnI, which has a unique site on the plasmid DNA, whereas no signal was observed for the wild-type isolate 506/2 (Fig. 6). A single integration event was observed in isolate GPD-18 denoted by two hybridizations signals, and multiple copy inserts of pGPD-GUS were observed in the transformed isolates GPD-1, GPD-7, GPD-8, and GPD-19 (Fig. 6). Although GPD-1 and GPD-19 contained multiple inserts, GUS activity was not proportional to plasmid number, since GPD-8 and GPD-18, containing single and double inserts, expressed GUS activity at a similar rate (Table 1; Fig. 6).

\section{DISCUSSION}

The cause of mango malformation disease, recognized for over a century, has been attributed to numerous agents including viral, acarological, physiological, and fungal factors $(11,22)$. F. subglutinans has been the fungal pathogen most commonly associated with the disease since 1966 (29); however, a recent article does not mention this organism as a possible source of infection (13). In light of past and present uncertainty regarding the causal disease agent, this study was conducted to (i) unequivocally determine the etiology of mango malformation disease using GUS transformants of $F$. subglutinans that are known to incite disease and (ii) track the fungus in infected tissue for confirmation.

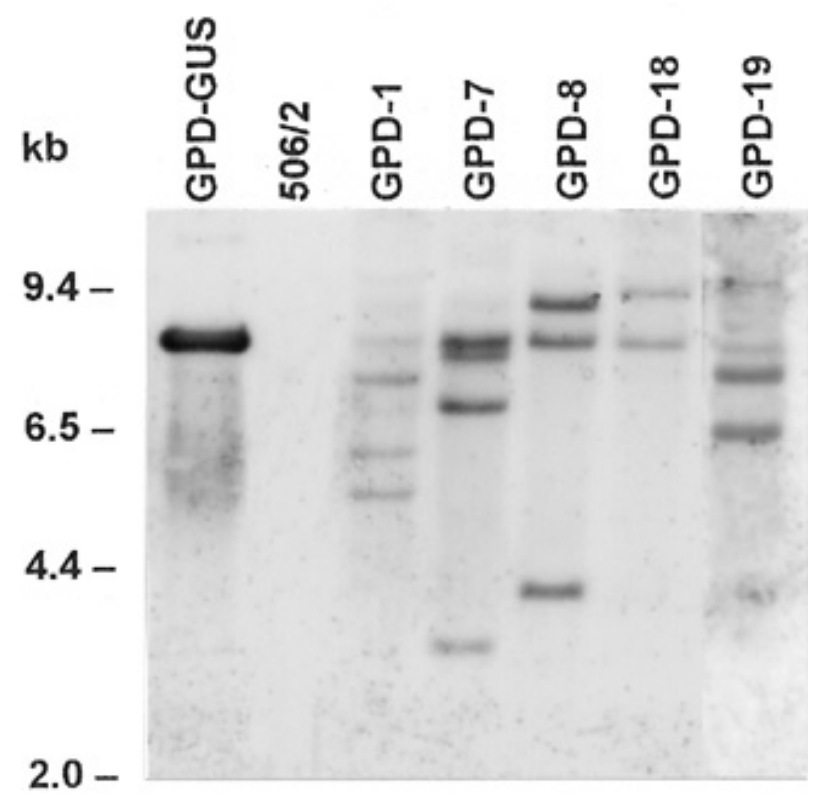

Fig. 6. Southern blot analysis of KpnI-linearized pGPD-GUS and KpnI-digested genomic DNA from the wild-type isolate 506/2 of Fusarium subglutinans and transformants (GPD-1, GPD-7, GPD-8, GPD-18, and GPD-19) probed with chemiluminescent-labeled pGPD-GUS. DNA size markers are indicated on the left. 
The wild-type isolate 506/2 of F. subglutinans, originating from infected malformed mango floral tissue, was readily transformed with the GUS reporter gene, producing transformants with stable single and multiple integration events (Fig. 6). All transformants maintained their GUS activity in vitro and in planta, and no differences in levels of staining were observed among the transformants, regardless of plasmid copy number, integration sites, or specific GUS activity. Transformants harboring multiple plasmid copies did not necessarily express elevated GUS activity compared with those containing single or double inserts. This indicates that transformants with multiple insertions may contain nonfunctional, truncated copies of the plasmid that are not expressed, besides a single functional insert. The GUS-transformed isolates expressing GUS activity remained pathogenic, causing typical vegetative and floral malformation symptoms in mango (Figs. 2 and 3). Disease symptoms were also achieved by placing a conidial drop on dormant buds without wounding, which further demonstrates the virulence of this pathogen. No other fungi were isolated or observed in noninoculated healthy tissue. This rules out the possibility that other unidentified fungal agents were present within plant tissue. The ensuing histochemical study detecting GUS-stained mycelium in infected tissues provided further evidence that $F$. subglutinans is a causal agent of mango malformation disease. GUS-stained pollen grains were also observed (data not shown), which suggests that the fungus could be spread by insects, wind, and other means during pollination. Although mites have been associated with mango malformation, acaricides were routinely applied to plants in our experiments to ensure that mites had no effect on the current results.

In summary, the wild-type isolate 506/2 of $F$. subglutinans, transformed with the GUS reporter gene, produced transformants with stable, single, and multiple integration events. GUS-transformed isolates expressing GUS activity remained pathogenic, causing typical vegetative and floral malformation symptoms in mango. Histochemical studies detected GUS-stained mycelium in infected tissues, providing unequivocal evidence that this strain of $F$. subglutinans and its transformants are causal agents of mango malformation. Future work will concentrate on the epidemiology of disease, since long-distance and within-tree spread of the fungus is poorly understood.

\section{ACKNOWLEDGMENTS}

Contribution No. 505/98 from the Agricultural Research Organization, Institute of Plant Protection, Bet Dagan, Israel. This research was supported, in part, by grant No. 132-0972-98 from the Chief Scientist, Israeli Ministry of Agriculture and the Fruit Board of Israel. We thank K. O'Donnell and E. Cigelnik, NCAUR, USDA-ARS, Peoria, IL, for providing sequence data of our isolates from mango. We also thank D. Straney, University of Maryland, for providing pGPD-GUS.

\section{LITERATURE CITED}

1. Abo-El Dahab, M. K. 1977. Correcting malformation symptoms of mango tree in Egypt by soil application of iron chelates. Egypt. J. Phytopathol. 7:97-99.

2. Burns, W., and Paryag, S. H. 1920. The Book of the Mango. Bull. Dep. Agric., Bombay, India.

3. Crookes, C. A., and Rijkenberg, F. H. J. 1985. Isolation of fungi associated with blossom malformation of mangoes. S. Afr. Mango Grower's Assoc. Res. Rep. 5:10-14.

4. Dickman, M. B., and Partridge, J. E. 1989. Use of molecular markers for monitoring fungi involved in stalk rot of corn. Theor. Appl. Genet. 77: 535-539.

5. Freeman, S., Pham, M., and Rodriguez, R. J. 1993. Molecular genotyping of Colletotrichum species based on arbitrarily primed PCR, A+T-rich DNA and nuclear DNA analyses. Exp. Mycol. 17:309-322.
6. Gallagher, S. R. 1992. GUS Protocols: Using the GUS Gene as a Reporter of Gene Expression. Academic Press, San Diego, CA.

7. Hassan, A. S. 1944. Notes on Eriophyes mangifera S. N. (Acarina). Bull. Soc. Fouad. Entomol. 28:179-180.

8. Jefferson, R. A. 1987. Assaying chimeric genes in plants: The GUS gene fusion system. Plant Mol. Biol. Rep. 5:387-405.

9. Kishtah, A. A., Nyland, G., Nasr El-Din, T. M., Tolba, M. A., Lowe, S. K., Khalib, E. M., Tadros, M. R., and El-Amrely, A. 1985. Mango malformation disease in Egypt. I. Electron microscopy, effect of antibiotics, cultural and serological studies. Egypt. J. Phytopathol. 17:151-157.

10. Kumar, J., and Beniwal, S. P. S. 1992. Role of Fusarium species in the etiology of mango malformation. Page 17 in: Int. Mango Symp. University of Florida, IFAS, Tropical Research and Education Center, and International Society for Horticultural Science, Miami Beach, FL.

11. Kumar, J., Singh, U. S., and Beniwal, S. P. S. 1993. Mango malformation: One hundred years of research. Annu. Rev. Phytopathol. 31:217-232.

12. Leslie, J. F., and Dickman, M. B. 1991. Fate of DNA encoding hygromycin resistance after meiosis in transformed strains of Gibberella fujikuroi (Fusarium moniliforme). Appl. Environ. Microbiol. 57:1423-1429.

13. Majumder, P. K., and Sharma, D. K. 1990. Mango. Pages 40-60 in: Fruits: Tropical and Subtropical. T. K. Bose and S. K. Mitra, eds. Naya Prokash, Calcutta, India.

14. Manicom, B. Q. 1989. Blossom malformation of mango. S. Afr. Mango Grower's Assoc. Yearb. 10:11-12.

15. Minessy, F. A., Biely, M. P., and El-Fahl, A. 1971. Effect of iron chelates in correcting malformation of terminal bud growth in mango. Sudan Agric. J. 6:71-74

16. Narasimhan, M. J. 1954. Malformation of panicles in mango incited by a species of Eriophyes. Curr. Sci. 23:297-298.

17. O’Donnell, K., and Cigelnik, E. 1997. Two divergent intragenomic rDNA ITS2 types within a monophyletic lineage of the fungus Fusarium are nonorthologous. Mol. Phylogenet. Evol. 7:103-116.

18. O'Donnell, K., Cigelnik, E., and Nirenberg, H. I. 1998. Molecular systematics and phylogeography of the Gibberella fujikuroi species complex. Mycologia 90:465-493.

19. Oliver, R. P., Farman, M. L., Jones, J. D. G., and Hammond-Kosack, K. E. 1993. Use of fungal transformants expressing $\beta$-glucuronidase activity to detect infection and measure hyphal biomass in infected plant tissues. Mol. Plant-Microbe Interact. 6:521-525.

20. Ploetz, R. C. Malformation: A unique and important disease of mango, Mangifera indica L. In: Fusarium: Paul E. Nelson Memorial Symposium. B. A. Summerell, ed. The American Phytopathological Society, St. Paul, MN. In press.

21. Ploetz, R. C., and Gregory, N. F. 1993. Mango malformation in Florida: Distribution of Fusarium sp. in affected trees, and relationships among strains within and among different orchards. Acta Hortic. 341: 388-394.

22. Ploetz, R. C., Zentmyer, G. A., Nishijima, W. T., Rohrbach, K. G., and Ohr, D., eds. 1994. Compendium of Tropical Fruit Diseases. The American Phytopathological Society, St. Paul, MN.

23. Powell, W. A., and Kistler, H. C. 1990. In vivo rearrangement of foreign DNA by Fusarium oxysporum produces linear self-replicating plasmids. J. Bacteriol. 172:3163-3171.

24. Redman, R. S., and Rodriguez, R. J. 1994. Factors which affect efficient transformation of Colletotrichum species. Exp. Mycol. 18:230-246.

25. Sambrook, J., Fritsch, E. F., and Maniatis, T. A. 1989. Molecular Cloning: A Laboratory Manual. 2nd ed. Cold Spring Harbor Laboratory, Cold Spring Harbor, NY.

26. Sattar, A. 1946. Diseases of mango in the Punjab. Punjab Fruit J. 10:56-58.

27. Singh, L. B., Singh, S. M., and Nirvan, R. S. 1961. Studies on mango malformation: Review, symptoms, extent, intensity and cause. Hortic. Adv. 5:197-207

28. Stomp, A.-M. 1992. Histochemical localization of $\beta$-glucuronidase. Pages 103-113 in: GUS Protocols: Using the GUS Gene as a Reporter of Gene Expression. S. R. Gallagher, ed. Academic Press, San Diego, CA.

29. Summanwar, A. S., Raychaudhuri, S. P., and Pathak, S. C. 1966. Association of the fungus Fusarium sp. Sheld. with the malformation in mango. Indian Phytopathol. 19:227-228.

30. Thrane, C., Lübeck, M., Green, H., Degefu, Y., Allerup, S., Thrane, U., and Jensen, D. F. 1995. A tool for monitoring Trichoderma harzianum: I. Transformation with the GUS gene by protoplast technology. Phytopathology 85:1428-1435.

31. Varma, A., Lele, V. C., Raychoudhuri, S. P., Ram, A., and Sang, A. 1974. Mango malformation: A fungal disease. Phytopathol. Z. 79:254-257. 